\title{
Immunoradiometric and Luminescence Immunoenzymometric Assay of Human Thyrotropin from Dried Blood Spots for Screening of Neonatal Hypothyroidism
}

\author{
Veleslava Jirkalová ${ }^{1}$, Jan Čáp ${ }^{1}$, Hana Straková ${ }^{2}$,Jaroslava Pribyšová ${ }^{1}$, Jan Plicka ${ }^{3}$ and Radovan Lomský1 \\ 1 Centrum pro hormonální proteiny a peptidy, Lékařská fakulta Karlovy university a Fakultní nemocnice, \\ Hradec Králové, Česká republika \\ 2 Tkáňová ústředna, Fakultni nemocnice, Hradec Králové, Česká republika \\ 3 Immunotech a. s., Praha, Česká republika
}

Summary: Two monoclonal antibodies to thyrotropin prepared in our laboratory were employed for the development of two-site immunometric assays in two modifications for the estimation of human thyrotropin in dried blood spots designed for the screening of neonatal hypothyroidism. The immunoradiometric assay using the second antibody labelled with ${ }^{125} \mathrm{I}$ is simple and fast (one incubation step lasting $2 \mathrm{~h}$ ). The detection limit of $1 \mathrm{mU} / 1$ and the absence of the hook effect up to a concentration of more than $1000 \mathrm{mU} / 1$ are optimal for neonatal screening; the presence of other glycoprotein hormones does not interfere with the assay. In the luminescence immunoenzymometric assay the second antibody is labelled with peroxidase. In spite of the two-step configuration the method is fast $(4.5 \mathrm{~h})$ and enables specific determination of thyrotropin levels in the range of $2.4-1100 \mathrm{mU} / \mathrm{l}$. The conditions and properties of both immunometric assays described are comparable with the time-resolved immunofluorometric assay widely used in Europe.

The luminescence immunoenzymometric assay was applied successfully in the screening of 3000 neonates for congenital hypothyroidism.

\section{Introduction}

The incidence of neonatal hypothyroidism in the USA and in Europe is 1/4000, with differences in European countries from $1 / 3000$ to $1 / 6000$ (1). The determination of the level of thyrotropin in dried blood spots is now widely considered to be the optimal method for the screening of neonatal hypothyroidism (2). For this purpose a number of methods have been developed and immunometric assays based on two antibodies have been used almost exclusively in the past ten years. The combinations used involved two polyclonal antibodies (3-5), one monoclonal and one polyclonal antibody (6) and, most recently, a pair of monoclonal antibodies $(7-10)$.

In this study we present a simple, rapid, specific and sensitive immunoradiometric assay and its non-isotopic variety - the luminescence immunoenzymometric assay - for the measurement of thyrotropin in dried blood spots for the screening of neonatal hypothyroidism using our own monoclonal antibodies to thyrotropin.

\section{Materials and Methods}

Hormones

The starting material for the isolation of human thyrotropin was the glycoprotein fraction obtained from frozen pituitaries using the method of Lumley Jones et al. (11). Following precipitation at a final ethanol volume fraction of 0.75 , the precipitate was dissolved in $100 \mathrm{mmol} / 1 \mathrm{NH}_{4} \mathrm{HCO}_{3}$ and applied to a column of Sephacryl S$100 \mathrm{HR}$. The glycoprotein hormone-containing fractions were pooled and freeze-dried. Thyrotropin was isolated from the freezedried material by consecutive chromatography on S-Sepharose Fast Flow, DEAE-cellulose (DE-52 Whatman), CM-cellulose (CM-52 Whatman), and Sephadex G-100 Superfine. All chromatographies were monitored using RIA for thyrotropin, follitropin, and lutropin. The resulting preparation of thyrotropin had an immunologic activity of $8.1 \mathrm{U} / \mathrm{mg}$ when measured in an IRMA system against the second IRP $80 / 558$ and it contained only negligible traces of follitropin and lutropin.

Human somatotropin was isolated from frozen pituitaries by a modification of the method of Lumley Jones et al. (11). The resultant preparation of somatotropin had a specific potency of $3.1 \mathrm{U} / \mathrm{mg}$ when measured by RIA against the first IRP 66/217.

Human prolactin was isolated from frozen pituitaries by a modification of the method of Hw'ang et al. (12) and had a potency of $31.16 \mathrm{U} / \mathrm{mg}$ when measured by RIA against the third IS $84 / 500$.

Second IS $80 / 552$ was used as the standard for human lutropin, first IS $83 / 575$ was used as the standard for human follitropin and third IS 75/537 was used as the standard for human chorionic gonadotropin.

\section{Monoclonal antibodies}

Using methods found in the literature (13) we prepared 273 mouse monoclonal antibodies to thyrotropin. For the construction of the immunometric systems, two antibodies were chosen that could bind the thyrotropin (TSH) molecule simultaneously. The TSH-5I 
antibody of an $\lg _{2 i 1}$ subclass is strictly specific for thyrotropin with an association constant of $5.5 \times 10^{10} \mathrm{l} / \mathrm{mol}$ and has a strong capacity to bind the hormone on the solid phase. The TSH-116 antibody of an $\operatorname{lgG}_{2 a}$ subclass binds the $\beta$-subunit of thyrotropin with an association constant of $1.1 \times 10^{11} \mathrm{l} / \mathrm{mol}$. It cross-reacts considerably with other glycoprotein hormones, which is of no significance in the present configuration. of the assay system (see below). Both antibodies have a high speed of reaction. The isolation of antibodies from ascitic fluid was performed by chromatography on a column of Protein-A Sepharose CL-4B (14).

\section{Preparation of standards}

Standards for immunoradiometric assay (IRMA) were prepared by adding the international reference preparation of thyrotropin (second IRP 80/558) in concentrations of $0,5,15,30,80$ and 160 $\mathrm{mU} / \mathrm{l}$ to heparinized blood with a thyrotropin content lower than $0.05 \mathrm{mU} / \mathrm{l}$. After thorough mixing, blood-spots were prepared on Schleicher-Schuell No. 2992 filter paper. After drying at room temperature for $4 \mathrm{~h}$ the standards were stored at $4^{\circ} \mathrm{C}$.

For the investigation of the cross-reactions, spots of blood with $200 \mu \mathrm{g} / \mathrm{l}$ prolactin, $100 \mu \mathrm{g} / \mathrm{l}$ somatotropin, $100 \mathrm{U} / \mathrm{l}$ chorionic gonadotropin, $100 \mathrm{U} / \mathrm{l}$ lutropin and $100 \mathrm{U} / \mathrm{l}$ follitropin were prepared. These hormones were added both to blood with zero concentration of thyrotropin and to blood containing $36 \mathrm{mU} / \mathrm{l}$ thyrotropin.

Standards for luminescence immunoenzymometric assay were prepared by adding thyrotropin in $10 \mathrm{mmol} / 1$ phosphate buffer, $\mathrm{pH} 7.4$, to a special matrix consisting of human serum (with thyrotropin concentration lower than $0.03 \mathrm{mU} / \mathrm{l}$ ) mixed with erythrocytes to give a physiological haematocrit ratio, the volume of the buffered thyrotropin standard not exceeding $5 \%$ of the matrix. Standards with thyrotropin concentrations of $0,12,30,70$ and $160 \mathrm{mU} / \mathrm{l}$, respectively, were pipetted in a volume of $50 \mu \mathrm{l}$ on SchleicherSchuell No. 2992 filter paper, dried at room temperature and stored at $4{ }^{\circ} \mathrm{C}$.

\section{Immunoradiometric assay}

Polystyrene tubes were pretreated with an aqueous solution of glutaraldehyde, $10 \mathrm{~g} / \mathrm{l}$, (Merck) for 4 hours. After washing with distilled water, $0.5 \mathrm{ml}$ of a solution of monoclonal antibody TSH- 51 in a concentration of $5 \mathrm{mg} / \mathrm{l}$ in phosphate-buffered saline, $\mathrm{pH} 7.5$, was added and incubated overnight at room temperature. After subsequent washing with phosphate-buffered saline, the remaining binding sites were blocked by incubation with a $10 \%$ solution of bovine serum in phosphate-buffered saline.

A $4 \mathrm{~mm}$ disc cut out of the blood spot and $200 \mu \mathrm{l}$ of a solution of ${ }^{125}$ I labelled monoclonal antibody TSH-116 were added to these tubes. The labelled antibody was dissolved in phosphate-buffered saline containing $1 \mathrm{~g} / \mathrm{l}$ bovine serum albumin to give a total activity of 60000 counts per minute per tube. After an incubation for $2 \mathrm{~h}$ at room temperature, both the solution and the disc were discarded, the tubes were rinsed twice with phosphate-buffered saline and the bound radioactivity counted in a gamma-counter. Both the standards and the samples were run in duplicate.

The detection limit was estimated by measuring the $0 \mathrm{mU} / \mathrm{l}$ standard in 15 tubes and calculating from the standard curve the concentration corresponding to the mean enlarged by two standard deviations of the mean.

The standards containing 15,30 and $80 \mathrm{mU} / \mathrm{h}$ of thyrotropin were measured in duplicate in five consecutive assays (inter-assay evaluation) and in twelve tubes in a single assay (intra-assay evaluation). The mean and standard deviation were calculated and the precision expressed as the coefficient of variation (standard deviation in percent of the mean).

\section{Luminescence immunoenzymometric assay}

Monoclonal antibody TSH-51 was bound on the solid phase of 96-well white plates (Immunotech, Prague) according to the method of Immunotech (European patent EP 0122209 Al). A $4.8 \mathrm{~mm}$ disc cut out of the blood spot on filter paper and 100

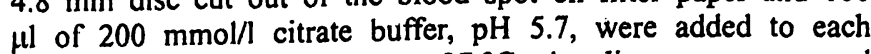
well. After shaking for $2 \mathrm{~h}$ at $37^{\circ} \mathrm{C}$, the discs were removed and the wells washed once. Phosphate-buffered saline containing the conjugate of the TSH-116 antibody with horseradish peroxidase $(150 \mu \mathrm{l})$, was added to the wells. The conjugate of the antibody with horseradish peroxidase was prepared with the twostep glutaraldehyde technique (15). After shaking for $2 \mathrm{~h}$ at $37^{\circ} \mathrm{C}$ and subsequent washing, $200 \mu$ l of the signal solution containing $1.95 \mathrm{mmol} / \mathrm{l}$ hydrogen peroxide, $290 \mu \mathrm{mol} / \mathrm{l}$ luminol and $45 \mu \mathrm{mol} / / p$-iodophenol was added $(16,17)$. The intensity of the light emitted was measured between 5 and $20 \mathrm{~min}$ on the LIANA luminometer (Immunotech, Prague).

The detection limit was estimated by measuring the $0 \mathrm{mU} / \mathrm{l}$ standard in 15 tubes and calculating from the calibration curve the concentration corresponding to the mean enlarged by two standard deviations of the mean.

The standards containing 15,30 and $70 \mathrm{mU} / \mathrm{h}$ of thyrotropin were measured in duplicate in twenty consecutive assays (inter-assay evaluation) and in twelve tubes in a single assay (intra-assay evaluation). The mean and standard deviation were calculated and the precision expressed as the coefficient of variation (standard deviation in percent of the mean). To estimate the precision profile, coefficients of variation of 960 duplicates (standards, control and unknown samples) measured in twenty assays were used. The mean coefficients of variation were calculated for individual $5 \mathrm{mU} / \mathrm{h}$ intervals of thyrotropin concentration and plotted against the thyrotropin concentration in the range of $1-200 \mathrm{mU} / \mathrm{l}$. The curve was fitted using the polynomic function of the 6 th degree.

\section{Results}

\section{Immunoradiometric assay}

A typical standard curve of the immunoradiometric assay of thyrotropin is shown in figure 1 . When the calibration was extended to $1000 \mathrm{mU} / \mathrm{l}$, no hook effect was present and the signal continued to increase.

The detection limit was $1.0 \mathrm{mU} / 1$. The results with blood spots containing other hormones added are shown in table 1 .

The intra-assay and inter-assay precision for three concentrations of thyrotropin is shown in table 2 .

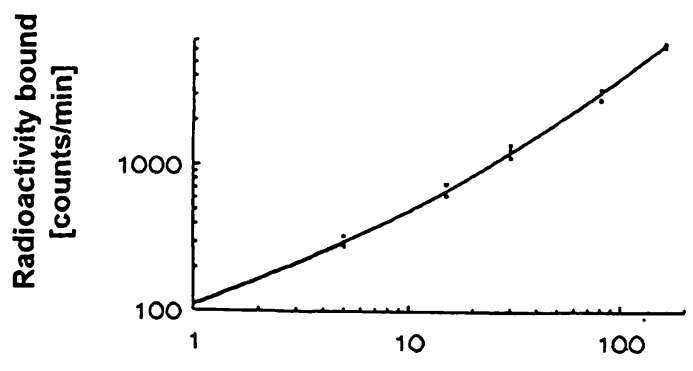

Thyrotropin [mU/I]

Fig. 1 Typical standard curve for the immunoradiometric assay of thyrotropin from dried blood spots.

The curve is fitted by the spline smoothed method. On the ordinate: measured radioactivity in counts per minute, logarithmic scale. On the abscissa: log of concentrations of thyrotropin standards. 


\section{Luminescence immunoenzymometric assay}

A typical standard curve of the luminescence immunoenzymometric assay of thyrotropin is shown in figure 2 . The light intensity proved to increase up to a thyrotropin concentration of $1100 \mathrm{mU} / \mathrm{l}$. The detection limit was $2.4 \mathrm{mU} / \mathrm{l}$.

The intra-assay and inter-assay precision for three concentrations of thyrotropin is shown in table 2. The precision profile is shown in figure 3. The functional detection limit, defined as the concentration of thyrotropin measured with imprecision less than 15 percent, was $12 \mathrm{mU} / \mathrm{l}$.

Thanks to the Prague Neonatal Screening Centre we were able to use the present luminescence immunoenzymometric method on blood spots from 3000 neonates that had been screened for neonatal hypothyroidism by

Tab. 1 Levels of thyrotropin determined in blood spots with the known concentration of hormone standards.

\begin{tabular}{|c|c|c|}
\hline Possible interferent & $\begin{array}{l}\text { Human } \\
\text { thyro- } \\
\text { tropin } \\
\text { (mU/l) }\end{array}$ & $\begin{array}{l}\text { Measured } \\
\text { value of human } \\
\text { thyrotropin } \\
(\mathrm{mU} / \mathrm{l})\end{array}$ \\
\hline \multicolumn{3}{|c|}{ Human chorionic gonadotropin } \\
\hline $\begin{array}{l}100 U / 1 \\
100 U / 1\end{array}$ & $\begin{array}{r}0 \\
36\end{array}$ & $\begin{array}{l}<1.0 \\
38.1\end{array}$ \\
\hline \multicolumn{3}{|l|}{ Human lutropin } \\
\hline $\begin{array}{l}100 \mathrm{U} / 1 \\
100 \mathrm{U} / 1\end{array}$ & $\begin{array}{r}0 \\
36\end{array}$ & $\begin{array}{r}1.3 \\
38.7\end{array}$ \\
\hline \multicolumn{3}{|l|}{ Human follitropin } \\
\hline $\begin{array}{l}100 \mathrm{U} / 1 \\
100 \mathrm{U} / 1\end{array}$ & $\begin{array}{r}0 \\
36\end{array}$ & $\begin{array}{l}<1.0 \\
37.0\end{array}$ \\
\hline \multicolumn{3}{|l|}{ Human prolactin } \\
\hline $\begin{array}{l}200 \mu \mathrm{g} / 1 \\
200 \mu \mathrm{g} / 1\end{array}$ & $\begin{array}{r}0 \\
36\end{array}$ & $\begin{array}{r}2.3 \\
35.6\end{array}$ \\
\hline \multicolumn{3}{|l|}{ Human somatotropin } \\
\hline $\begin{array}{l}100 \mu \mathrm{g} / \mathrm{l} \\
100 \mu \mathrm{g} / \mathrm{l}\end{array}$ & $\begin{array}{r}0 \\
36\end{array}$ & $\begin{array}{l}<1.0 \\
34.8\end{array}$ \\
\hline
\end{tabular}

Tab. 2 The precision of measurement expressed as the intra-assay and inter-assay coefficients of variation.

\begin{tabular}{llc}
\hline $\begin{array}{l}\text { Thyrotropin } \\
\text { concentration } \\
\text { (mU/1) }\end{array}$ & \multicolumn{2}{c}{ Coefficient of variation in \% } \\
\cline { 2 - 3 } & Intra-assay & Inter-assay \\
\hline Immunoradiometric assay & & \\
15 & 8.3 & 9.3 \\
30 & 8.1 & 8.7 \\
80 & 7.0 & 5.0 \\
& & \\
Luminescence immunoenzymometric assay & \\
15 & 8.6 & 12.4 \\
30 & 6.8 & 8.2 \\
70 & 7.1 & 5.5 \\
\hline
\end{tabular}

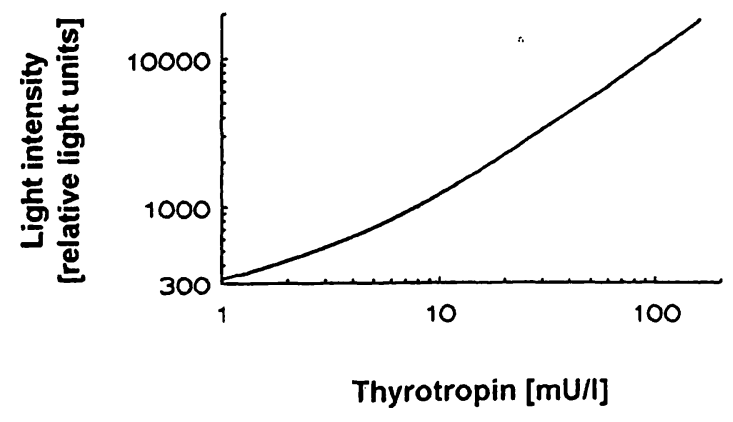

Fig. 2 Typical standard curve for the luminescence immunoenzymometric assay of thyrotropin from dried blood spots. The curve is fitted by the spline smoothed method. On the ordinate: measured light intensities in relative light units, logarithmic scale. On the abscissa: log of concentrations of thyrotropin standards.

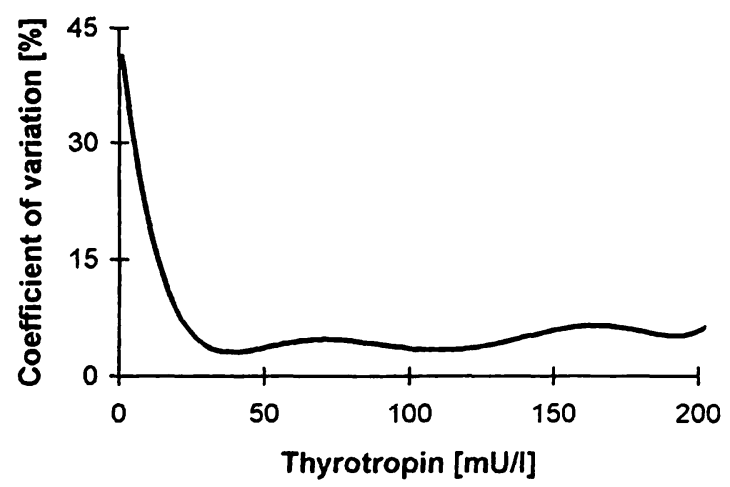

Fig. 3 Precision profile of the present luminescence immunoenzymometric assay.

The curve is fitted using the polynomic function of the 6th degree. On the ordinate: mean coefficient of variation in percent. On the abscissa: measured thyrotropin concentration.

methods including the Pharmacia Dry Spot TSH IRMA kit in the preceding three years. Positive samples were preferentially included. The concentration of thyrotropin in the vast majority of all samples under comparison proved to be lower than $20 \mathrm{mU} / \mathrm{l}$ (the cut-off level for positives used in the Screening Centre) by both methods. Higher concentrations were found in 15 cases by the present luminescence immunoenzymometric method and in 16 cases by the Dry Spot TSH IRMA method. The only differing sample value could not be classified as controversial, because both values $(20.2 \mathrm{mU} / \mathrm{l}$ for IRMA and $16.6 \mathrm{mU} / 1$ for luminescence immunoenzymometric assay) were very close to the cut-off border value of $20 \mathrm{mU} / \mathrm{l}$. To perform a more exact comparison of the two methods, various amounts of thyrotropin were added to 32 control blood samples up to a concentration of $200 \mathrm{mU} / \mathrm{l}$, the samples were assayed simultaneously with both kits and the values obtained were studied by the $x / y$ method. The result is presented in figure 4 . The mean $x / y$ was 0.982 and the coefficient of variation was 14.1 percent.

\section{Discussion}

The immunoradiometric assay for the determination of thyrotropin from dried blood spots described in this pa- 


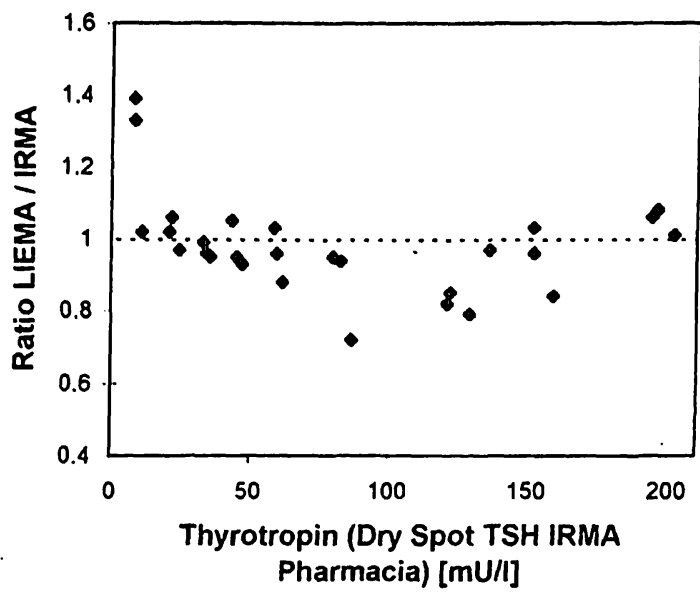

Fig. 4 Correlation between thyrotropin concentrations measured by our luminescence immunoenzymometric assay (LIEMA) and by the Pharmacia Dry Spot TSH IRMA kit (IRMA). On the ordinate: ratio LIEMA/IRMA. On the abscissa: thyrotropin concentration measured by the Dry Spot TSH IRMA kit. The mean ratio was 0.982 and the coefficient of variation was 14.10 .

per is simple, easy to perform and rapid. The detection limit of $1 \mathrm{mU} / \mathrm{l}$ is quite sufficient, as the levels below $20 \mathrm{mU} / \mathrm{l}$ are considered negative in the screening of neonatal hypothyroidism (18). A very low detection limit $(0.037 \mathrm{mU} / \mathrm{l})$ was described in an assay of Japanese researchers based on a combination of monoclonal antibody and polyclonal antibody (6). However, sensitivity in this range is not necessary for the screening of primary hypothyroidism. The continuing increase of the standard curve up to $1000 \mathrm{mU} / \mathrm{l}$ is more than adequate. In spite of the fact that the labelled antibody used crossreacted with other glycoprotein hormones, the results were not influenced by the presence of $100 \mathrm{U} / 1$ each of lutropin, follitropin and chorionic gonadotropin. These levels are not exceeded in the blood of neonates (6).

\section{References}

1. Tuoblanc JE. Comparison of epidemiological data on congenital hypothyroidism in Europe with those of other parts in the world. Horm Res 1992; 38:233-5.

2. Bourdoux PP, Van Thi HV, Courtois PA, Ermans AM. Superiority of thyrotropin to thyroxine as a tool in the screening for congenital hypothyroidism by the filter paper spot technique. Clin Chim Acta 1991; 195:97-105.

3. Miyai $M$, Tsuruhara $T$, Kusuda $S$, Ischibashi $K$, Kawashima $M$, Mizura $H$, et al. Semiautomated enzyme immunoassay of thyrotropin as a mass screening test for neonatal hypothyroidism. Pediatr Res 1984; 18:1289-92.

4. Torresani T, Quing Q, Illig R. Thyrotropin enzyme-immunoassay in dried blood spots: a spectrophotometric method for neonatal thyroid screening. J Clin Chem Clin Biochem 1986; 24:199-203.

5. Waite KV, Maberly GF, Ma G, Eastman CJ. Immunoradiometric assay with use of magnetizable particles: measurement of thyrotropin in blood spots, to screen for neonatal hypothyroidism. Clin Chem 1986; 32:1966-8.

6. Hashida S, Tanaka K, Kohno T, Ishidawa E, Umehashi $H$, Hayashida $T$, et al. A highly sensitive sandwich enzyme immunoassay of human thyroid-stimulating hormone in dried blood on filter paper discs for mass-screening of neonatal hypothyroidism. J Clin Lab Anal 1986; 1:198-204.
However, the immunoradiometric assay for thyrotropin served only as the springboard for the development of the luminescence immunoenzymometric assay for clinical purposes and for this reason we have not examined any real patient samples.

The advantage of the luminescence immunoenzymometric assay is the longer stability of the labelled antibody and that its use is not limited to isotope laboratories. It was not, however, possible to perform it in a one-step modification, because the enzymatic reaction was influenced by the presence of blood. Therefore it was necessary to perform a two-step method and to add one more wash. The precision seems to be comparable with the IRMA method; the detection limit is somewhat higher because of the higher signal of the zero standard (blank), but sufficient for the neonatal screening. In comparison with the immunochemiluminometric screening method used by Neto (10) the procedure described is simpler, because it is not necessary to pre-elute the disc, and more rapid, because no overnight incubation is necessary. There was no false positive result with real patient samples and the cases of neonatal hypothyroidism were properly recognized.

\section{Conclusion}

The conditions and properties of the immunoradiometric and luminescence immunoenzymometric assays described are adequate for the screening of neonatal hypothyroidism. They are comparable with the time-resolved immunofluorometric assay widely used in Europe $(7,8)$. The luminescence immunoenzymometric assay was applied successfully in the screening of 3000 neonates for congenital hypothyroidism.

7. Arends J, Norgaard-Pedersen B. Immunofluorometry of thyrotropin from whole-blood spots on filter paper to screen for congenital hypothyroidism. Clin Chem 1986; 32:1854-6.

8. Torresani TE, Scherz R. Thyroid screening of neonates without use of radioactivity: evaluation of time-resolved fluoroimmunoassay of thyrotropin. Clin Chem 1986; 32:1013-6.

9. Tuuminen T, Rakkolainen AEM, Welin MGI, Weber TH, Nylander PL, Käpyaho KI. A rapid fluorometric enzyme immunoassay for the determination of neonatal TSH from blood spots. Clin Chim Acta 1991; 202:167-78.

10. Neto EC. Neonatal hypothyroidism screening with immunochemiluminometric assay of thyrotropin. Clin Chem 1991; 37:1796.

11. Lumley Jones R, Benker G, Salacinski PR, Lloyd TJ, Lowry PJ. Large-scale preparation of highly purified pyrogen-free human growth hormone. J Endocrinol 1979; 82:77-86.

12. Hwang P, Robertson M, Guyda $H$, Friesen $H$. The purification of human prolactin from frozen pituitary glands. J Clin Endocrinol Metab 1973; 36:1110-8.

13. Köhler G, Milstein C. Continuous cultures of fused cells secreting antibody of predefined specificity. Nature 1975; 2566:495-7. 
14. Ey PL, Prowse SJ, Jenkin GR. Isolation of pure $\mathrm{IgG}_{1}, \mathrm{IgG}_{2 \mathrm{a}}$ and $\mathrm{IgG}_{2 \mathrm{~b}}$ immunoglobulins from mouse serum using protein A-sepharose. Immunochemistry 1978; 15:429-36.

15. Avrameas S, Terning T. Peroxidase labelled antibody and Fab conjugates with enhanced intracellular penetration. Immunochemistry $1971 ; 8: 1175-80$.

16. Thorpe GHP, Kricka LJ, Moseley SB, Whitehead TP. Phenols as enhancers of the chemiluminescence HRP-luminol- $\mathrm{H}_{2} \mathrm{O}_{2}$ reaction: application in luminescence monitored EIA. Clin Chem 1985; 31:1335-41.

17. Thorpe GHP, Kricka LJ. Enhanced chemiluminescent reaction catalysed by HRP. Methods Enzymol 1986; 133:331-53.
18. Leger J, Lemerrer M, Briard JL, Czernichow P. Hypothyroidism in children with filter paper TSH of 30 to $50 \mu \mathrm{IU} / \mathrm{ml}$ at initial screening. Acta Paediatr Scand 1987; 76:599-602.

Received April 9/July 8, 1996

Corresponding author: Dr. Veleslava Jirkalová, Centre for Protein and Peptide Hormones, Charles University School of Medicine, University Hospital, CZ-500 05 Hradec Králové, Czech Republic 
